\title{
Human intravenous immunoglobulin provides protection against $A \beta$ toxicity by multiple mechanisms in a mouse model of Alzheimer's disease
}

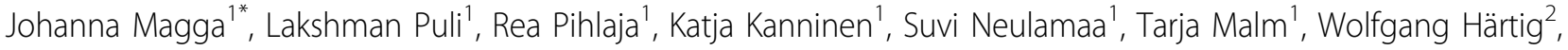
Jens Grosche ${ }^{2}$, Gundars Goldsteins ${ }^{1}$, Heikki Tanila ${ }^{1,3}$, Jari Koistinaho ${ }^{1,4,5}$, Milla Koistinaho ${ }^{1,6}$

\begin{abstract}
Background: Purified intravenous immunoglobulin (IVIG) obtained from the plasma of healthy humans is indicated for the treatment of primary immunodeficiency disorders associated with defects in humoral immunity. IVIG contains naturally occurring auto-antibodies, including antibodies (Abs) against $\beta$-amyloid (A $\beta$ ) peptides accumulating in the brains of Alzheimer's disease (AD) patients. IVIG has been shown to alleviate AD pathology when studied with mildly affected AD patients. Although its mechanisms-of-action have been broadly studied, it remains unresolved how IVIG affects the removal of natively formed brain A $\beta$ deposits by primary astrocytes and microglia, two major cell types involved in the neuroinflammatory responses.

Methods: We first determined the effect of IVIG on A $\beta$ toxicity in primary neuronal cell culture. The mechanismsof-action of IVIG in reduction of A $\beta$ burden was analyzed with ex vivo assay. We studied whether IVIG solubilizes natively formed A $\beta$ deposits from brain sections of APP/PS1 mice or promotes A $\beta$ removal by primary glial cells. We determined the role of lysosomal degradation pathway and A $\beta$ Abs in the IVIG-promoted reduction of A 3 . Finally, we studied the penetration of IVIG into the brain parenchyma and interaction with brain deposits of human $A \beta$ in a mouse model of $A D$ in vivo.
\end{abstract}

Results: IVIG was protective against A $\beta$ toxicity in a primary mouse hippocampal neuron culture. IVIG modestly inhibited the fibrillization of synthetic $A \beta 1-42$ but did not solubilize natively formed brain $A \beta$ deposits ex vivo. IVIG enhanced microglia-mediated $A \beta$ clearance ex vivo, with a mechanism linked to $A \beta$ Abs and lysosomal degradation. The IVIG-enhanced A $\beta$ clearance appears specific for microglia since IVIG did not affect A $\beta$ clearance by astrocytes. The cellular mechanisms of $A \beta$ clearance we observed have potential relevance in vivo since after peripheral administration IVIG penetrated to mouse brain tissue reaching highest concentrations in the hippocampus and bound selectively to $A \beta$ deposits in co-localization with microglia.

Conclusions: Our results demonstrate that IVIG promotes recognition and removal of natively formed brain $A \beta$ deposits by primary microglia involving natural A $\beta$ Abs in IVIG. These findings may have therapeutic relevance in vivo as IVIG penetrates through the blood-brain barrier and specifically binds to A $\beta$ deposits in brain parenchyma.

\section{Background}

Deposition of $\mathrm{A} \beta$ peptides is the major hallmark of $\mathrm{AD}$ in addition to neurofibrillary tangles formed by hyperphosphorylated tau [1]. The $\mathrm{A} \beta$ deposits consist primarily of fibrillized $A \beta 1-40$ and $A \beta 1-42$ peptides, the latter

\footnotetext{
* Correspondence: Johanna.Magga@uef.fi

'Department of Neurobiology, A. I. Virtanen Institute for Molecular Sciences, University of Eastern Finland, Kuopio, Finland

Full list of author information is available at the end of the article
}

being more prone to aggregation. The $A \beta$ deposits containing $A \beta$ peptide oligomers, diffuse $A \beta$ deposits and aggregated fibrillar $A \beta$ induce neurotoxicity and cognitive defects, as demonstrated in vitro and in vivo [1-4]. The A $\beta$ neurotoxicity may be largely regulated by microglia, the surveillant cells of the CNS [5], which may possess double-faced actions of conducting both pro-inflammatory and anti-inflammatory effects [6-9].
C Biomed Central 
The reduction of $\mathrm{A} \beta$ burden by passive immunization has been shown to alleviate neurodegeneration and cognitive defects in mouse models of AD [10-13]. There are numerous potential mechanisms that may regulate $A \beta$ levels in the brain. According to the peripheral sink hypothesis, $A \beta$ Abs in the plasma extract $A \beta$ via equilibrium in efflux of $A \beta$ across the blood-brain barrier (BBB) [14]. In the brain parenchyma, the reduction of $A \beta$ burden may be endogenously carried out by astroglia $[15,16]$ in addition to microglia, which have been demonstrated to participate in both deposition of $A \beta$ $[2,17]$ as well as reduction of $A \beta$ burden by phagocytosis or some other mechanisms [18-20]. Under certain circumstances, microglia-mediated $A \beta$ phagocytosis is enhanced after $A \beta$ deposits are opsonized with active or passive immunotherapy, and this $A \beta$ clearance is also associated with alleviation of cognitive defects or ADrelated neuropathological changes [10-14,21]. Immunization can also remarkably alleviate cognitive defects without reduction of $A \beta$ burden [22], possibly because of enhanced peripheral clearance or sequestration of soluble $A \beta$ peptides from the brain to blood [14,23-25]. Monoclonal Abs to $A \beta$ have also been shown to inhibit fibrillization of synthetic $A \beta$ peptide in vitro [26], thereby preventing the aggregation of $A \beta$.

IVIG, purified immunoglobulin obtained from the plasma of healthy humans is indicated for the treatment of primary immunodeficiency disorders associated with defects in humoral immunity. In addition, IVIG is used as an anti-inflammatory therapy for many systemic diseases, including diseases affecting the CNS [27]. Recently, a retrospective study suggested that previous IVIG treatment is associated with a reduced risk of developing AD and related disorders [28]. Furthermore, administration of IVIG to eight patients with mild AD led to transient, reproducible, and dose-dependent increases in serum anti-A $\beta$ Ab titers in parallel with increases in plasma $A \beta 1-40$ and $A \beta 1-42$ levels and improvement in memory functions [29].

Naturally occurring $A \beta$ Abs or specific immune complexes containing auto-Abs to $A \beta$ are significantly less frequent in $\mathrm{AD}$ patients than those in age-matched controls, suggesting that reduced levels of auto-Abs to $A \beta$ could lead to increased $A \beta$ deposition in AD [30-33]. Recently it was reported that $A \beta$ Abs abundant in human plasma are reactive against oligomeric $A \beta$, but the reactivity against oligomeric $A \beta$ assemblies declines with age and advancing $\mathrm{AD}$ [34]. Furthermore, IgG was detected in the brain and found to bind to brain $A \beta$ deposits while AD patients with high IgG plaque labeling index had reduced plaque burden which was accompanied with an elevated level of phagocytic microglia [35]. IVIG may serve as a potential therapy to compensate the deprivation of naturally occurring $A \beta$ Abs in
$\mathrm{AD}$ that would alleviate the $\mathrm{A} \beta$-induced toxicity. Alternatively, IgG antibodies unrelated to specific $A \beta$ Abs may have beneficial effects against $A \beta$ toxicity as IgG has been shown to protect brain also against acute brain injuries [36,37]. However, the detailed mechanisms how IVIG treatment improves the AD pathology and cognitive defects are unclear.

The potential and mechanisms-of-action of IVIG as an anti-inflammatory agent for a broad range of diseases is under intensive investigation. IVIG contains naturally occurring auto-Abs, including Abs against $A \beta[38,39]$ which are able to block synthetic $A \beta$ fibrillization and prevent $\mathrm{A} \beta$-mediated neurotoxicity in vitro [39]. IVIG has also been shown to dissolve pre-formed synthetic $A \beta$ fibrils in vitro, as well as to promote synthetic $A \beta$ uptake in BV-2 microglia, a murine microglia cell line [40]. However, it is still unsolved whether IVIG could actually dissolve natively pre-formed human $\mathrm{A} \beta$ deposits in brain and/or enhance the recognition and reduction of these $\mathrm{A} \beta$ deposits by primary microglia. Therefore, it is unclear whether the beneficial effects of IVIG observed in earlier in vitro studies using synthetic $A \beta$ have true relevance in $A \beta$ deposition and its possible reduction in $\mathrm{AD}$.

In this study we demonstrate that IVIG prevents $A \beta$ toxicity to hippocampal neurons and that the beneficial effect of IVIG may be mediated by direct neuroprotection as well as by enhanced microglia-mediated, but not astrocyte-mediated, clearance of natively formed diffuse human $A \beta$ deposits in the brain. This microglia-mediated clearance of $A \beta$ occurs by a mechanism involving $A \beta$ Abs present in IVIG and phagocytic degradation of $A \beta$. In line with the idea that IVIG treatment can result in microglia-mediated $\mathrm{A} \beta$ clearance, we demonstrate that peripherally administered IVIG penetrates into the brain parenchyma of transgenic AD mice and selectively binds to $A \beta$ deposits which are co-localized and surrounded with microglia.

\section{Methods}

\section{Animals}

The amyloid precursor protein and presenilin 1 transgenic (APP/PS1) breeder mice were obtained from Johns Hopkins University, Baltimore, MD, USA (D. Borchelt and J. Jankowsky, Department of Pathology), and a colony was established at the National Laboratory Animal Center, University of Eastern Finland. Briefly, mice were created by co-injection of chimeric mouse/ human APP695 harboring the Swedish mutation K595N/M596L and human PS1-dE9 (deletion of exon 9) vectors controlled by independent mouse prion protein promoter elements [41]. The double transgenic mice, APP/PS1, were backcrossed to C57BL6/J for 10-12 generations. Age-matched wild-type littermates served as 
controls. Animals were housed in a controlled environment, and food and water were available ad libitum. Animal experiments were conducted according to the Council of Europe legislation and regulations for animal protection and approved by the Animal Experiment Committee in State Provincial Office of Southern Finland.

\section{IVIG}

Purified IVIG (trade name Gammagard Liquid), prepared from the plasma of healthy humans, was kindly provided by Baxter Innovations $\mathrm{GmbH}$ (Vienna, Austria). The control IVIG, depleted of anti-A $\beta$ Abs with affinity chromatography, was also provided by Baxter. The concentration of $\mathrm{A} \beta \mathrm{Abs}$ is approximately $0.2 \%$ of all IgGs present in IVIG [42]. The anti-A $\beta$ depleted IVIG was determined to contain about $5 \%$ of its naturally occurring A $\beta$ Abs. The molarity of IVIG was counted based on the molecular weight of Ig, $150000 \mathrm{Da}$

\section{$A \beta$ neurotoxicity in hippocampal neuronal culture}

Primary hippocampal neuronal cultures from E18 C57BL mouse brains were prepared as described previously [43,44]. Briefly, after dissection and papaindissociation the hippocampi were suspended in Dulbecco's modified eagle medium (DMEM), 10\% FBS with penicillin-streptomycin (Gibco, Invitrogen) and plated on poly-DL-ornithine-precoated $(0.5 \mu \mathrm{g} / \mu \mathrm{l}$; Sigma) 48 well culture plates at 150000 cells $/ \mathrm{cm}^{2}$ and cultivated in humidified atmosphere at $37^{\circ} \mathrm{C}$ in $5 \% \mathrm{CO}_{2}$. The next day the medium was changed to serum-free Neurobasal culture medium supplemented with $2 \%$ B27, $500 \mu \mathrm{M}$ glutamine, $25 \mu \mathrm{M}$ glutamate, and penicillin-streptomycin (Gibco, Invitrogen). To obtain $\sim 90 \%$ pure neuronal culture, cells were treated with $10 \mu \mathrm{M}$ cytosine arabinoside (AraC, Sigma) at days 2-4 to prevent proliferation of other cell types. Thereafter, the whole medium was changed for supplemented Neurobasal to remove AraC, and in addition, one-third of the medium was changed every 3-4 days for maintenance. The hippocampal neurons were used for experiments after 11 days in vitro (DIV).

A 31 -42 (American Peptide) was dissolved to a stock solution of $1 \mathrm{mg} / \mathrm{ml}$ in sterile water. Hippocampal neurons were co-treated with freshly dissolved $A \beta 1-42$ and IVIG for $24 \mathrm{~h}$. Thereafter, the medium was collected and analyzed for lactate dehydrogenase (LDH) release (Sigma) according to the kit protocol. LDH assay measures membrane integrity as a function of the amount of cytoplasmic LDH released into the medium. Hippocampal neurons were fixed with $4 \%$ formaldehyde and stained with the bisbenzimide Hoechst 33342, (Sigma) for detection of apoptotic/necrotic cells. The cell viability was determined under the fluorescent microscope (Olympus IX71 microscope with MT10 illumination system attached to DP70 digital camera, running DP software, Olympus) based on the absence of condensed chromatin.

\section{$A \beta$ fibrillization}

A $\beta 1-42$ was dissolved to a stock solution of $1 \mathrm{mg} / \mathrm{ml}$ in sterile water. We have previously shown that $A \beta 1-42$ starts immediately and spontaneously to oligomerize and eventually fibrillize [44], being most toxic in oligomer-rich form immediately after being dissolved. To obtain fully fibrillized $A \beta$, the dissolved peptide was incubated at $37^{\circ} \mathrm{C}$ for $24 \mathrm{~h}$. The oligomerization state of $A \beta$ was analyzed with immunoblotting for human $A \beta$ (clone 6E10, Signet, Covance) after cross-linking the samples with glutaraldehyde as described previously [44]. The fibrillary state of $A \beta$ has been confirmed with electron microscopy as described previously [44].

The effect of IVIG on A $\beta$ fibrillization was studied by incubating freshly solubilized $10 \mu \mathrm{M} \mathrm{A} \beta 1-42$ in the presence or absence of 5, 10 and $30 \mu \mathrm{M}$ IVIG or $30 \mu \mathrm{M}$ of irrelevant human recombinant IgG (Baxter) as a control, at $37^{\circ} \mathrm{C}$ for $24 \mathrm{~h}$. PBS buffer was used as an additional control. The concentration of the fibrillar $A \beta$ was quantified fluorometrically using Thioflavin-T staining [45]. The samples were added to $2 \mu \mathrm{M}$ Thioflavin-T (Sigma) solution in $50 \mathrm{mM}$ glycine, $\mathrm{pH}$ 9.2. Fluorescence was measured at excitation and emission wavelengths of 435 and $485 \mathrm{~nm}$ respectively.

To study whether IVIG could solubilize natively preformed $A \beta$ deposits in brain, cryostat-cut brain sections of aged (19 month old) APP/PS1 mice were incubated in the presence or absence of $20 \mu \mathrm{M}$ IVIG in ex vivo medium consisting of X Vivo 15 (Lonza), penicillinstreptomycin and $2 \mathrm{mM} \mathrm{L-glutamine} \mathrm{(Gibco,} \mathrm{Invitrogen)}$ for 7 days after which the medium was collected and the $A \beta 1-42$ concentration was determined with $A \beta 1-42$ ELISA (Biosource). The brain sections were fixed with $4 \%$ formaldehyde in PBS for 30 min and analyzed for A $\beta$ content. Nonspecific binding sites were blocked with $10 \%$ normal goat serum (NGS) in $0.1 \%$ PBS-T. The sections were reacted with pan- $\mathrm{A} \beta \mathrm{Ab} 3 \mu \mathrm{g} / \mathrm{ml}$ (Biosource) in $1 \%$ NGS PBS-T overnight, followed by $10 \mu \mathrm{g} / \mathrm{ml}$ Alexa568 secondary Ab (Molecular Probes) for $2 \mathrm{~h}$ at room temperature (RT). The glass coverslips were mounted onto microscope slides using Vectashield containing nuclear stain DAPI (Vector Laboratories). The sections were imaged with an Olympus AX70 microscope attached to a digital camera (Color View 12 or F-View, Soft Imaging System) running an Analysis Software (Soft Imaging System) and quantified (Image ProPlus, Media Cybernetics) for the $A \beta$ burden as an indicator of solubilization of pre-formed $A \beta$ deposits. 
Degradation of brain $A \beta$ by primary microglia cells

Mixed microglia cell culture was prepared from P0-P1 C57BL mouse pups as described [46]. Briefly, the cortices and midbrain were dissected out and meninges were removed. The tissues were dissociated with trypsin and the cells were eventually resuspended into DMEM, $10 \% \mathrm{FBS}, 100 \mathrm{U} / \mathrm{ml}$ penicillin-streptomycin and $2 \mathrm{mM}$ L-glutamine (Gibco, Invitrogen). The cells were plated on cell culture flasks coated by poly-L-lysine (PLL, Sigma) and cultivated in humidified atmosphere at $37^{\circ} \mathrm{C}$ in $5 \% \mathrm{CO}_{2}$. The medium was changed after two days and thereafter every 2-3 days of cultivation. The loosely attached microglia were harvested after 12 DIV by shaking the flasks at $120 \mathrm{rpm}$ for $10-15 \mathrm{~min}$ at $37^{\circ} \mathrm{C}$ in an orbital shaker. For ex vivo experiments, microglia were resuspended in serum-free $\mathrm{X}$ Vivo 15 medium (Lonza) supplemented with penicillin-streptomycin and $2 \mathrm{mM}$ L-glutamine.

The ex vivo $\mathrm{A} \beta$ degradation assay was modified from Koistinaho et al. [15]. Aged APP/PS1 mice were perfused with heparinized saline and brain hemispheres were frozen on dry ice. Cryostat-cut (Leica) $10-\mu \mathrm{m}$-thick sagittal brain sections were mounted on PLL-coated glass coverslips and transferred onto 24- or 48-well cell culture plates and stored at $-20^{\circ} \mathrm{C}$ until use. Brain sections were thawed shortly before use and incubated with IVIG for $1 \mathrm{~h}$ at $37^{\circ} \mathrm{C}$, after which the cells were applied onto the brain sections, 250000 cells $/ \mathrm{cm}^{2}$ with or without IVIG. After $24 \mathrm{~h}$ of incubation, the sections were fixed and immunostained as described above. The sections were quantified as described above for the amount of remaining $A \beta$ immunostaining ( $A \beta$ burden) as an indicator for $A \beta$ clearance by the cells. IVIG concentrations higher than $20 \mu \mathrm{M}$ may cause an excess dilution of the cell culture medium and may not be relevant for in vivo conditions. Thus, IVIG concentrations $\leq 20 \mu \mathrm{M}$ were used.

To study IVIG interaction with $A \beta$ deposits in microglia-mediated $A \beta$ clearance, the brain sections were first incubated with IVIG for $1.5 \mathrm{~h}$ at $37^{\circ} \mathrm{C}$ and after wash out of any unbound IVIG, the microglia were applied as described above. After $24 \mathrm{~h}$ of incubation, reduction of $\mathrm{A} \beta$ burden was quantified as described above.

To elucidate the contribution of and the effect of IVIG on lysosomal degradation, the major intracellular protein degradation pathway in microglia-mediated $A \beta$ clearance, microglia ex vivo assay with or without IVIG was performed in the presence of $500 \mathrm{nM}$ bafilomycin A1 (Baf) (Sigma) to inhibit the lysosomal degradation pathway in microglia. After $24 \mathrm{~h}$ of incubation, the reduction of $A \beta$ burden was quantified.

The analysis of co-localization of $A \beta$ deposits and microglia was performed by imaging the same site of the brain section after exciting Alexa568 and DAPI fluorescence, respectively. The figures were merged with Adobe Photoshop. The count the number of microglia the same site of sections were imaged as described above and the cells were counted based on the nuclear stain DAPI present in the mounting medium.

Cell viability was determined by resazurin assay. After $24 \mathrm{~h}$ of incubation, $10 \mu \mathrm{M}$ resazurin (Sigma) was applied into cell culture medium and incubated for $4 \mathrm{~h}$. Medium samples were collected into 96-well plate and measured with excitation $544 \mathrm{~nm}$, emission $590 \mathrm{~nm}$ (Victor Wallac).

\section{Degradation of brain $A \beta$ by primary astrocytes}

Adult astrocyte cell culture was prepared as described before [15]. Briefly, hippocampi and cortices were isolated from 6-8-week-old C57BL mice and the tissues were dissociated with trypsin followed by Percoll (Sigma) centrifugation. The cells were eventually resuspended into DMEM/F12, 10\% FBS, $100 \mathrm{U} / \mathrm{mL}$ penicillin-streptomycin and G5 supplement (Gibco, Invitrogen), plated onto PLL-coated cell culture flasks and cultivated in humidified atmosphere at $37^{\circ} \mathrm{C}$ in $5 \% \mathrm{CO}_{2}$ for several passages. Before the experiments the glial cell cultures were shaken at $200 \mathrm{rpm}$ for $2 \mathrm{~h}$ at $37^{\circ} \mathrm{C}$ to remove microglia.

For ex vivo experiments, astrocytes were re-suspended in serum-free DMEM/F12 medium, 0.2\% BSA (Sigma), $100 \mathrm{U} / \mathrm{ml}$ penicillin-streptomycin and G5 supplement and applied onto the brain sections at $150000 \mathrm{cells} / \mathrm{cm}^{2}$ as described above.

\section{Penetration of IVIG into the brain}

To study the brain access of human IVIG, 4-month-old APP/PS1 mice or their wild-type littermate controls received i.p. injections of $1.0 \mathrm{~g} / \mathrm{kg}$ of $10 \%$ IVIG or equal volume $(10 \mathrm{ml} / \mathrm{kg})$ of saline. The short-term injections (1-3 weeks) were administered twice a week while the long-term injections were given once per week.

\section{Intrahippocampal injection of IVIG}

Intrahippocampal injections were performed as previously described [47]. Briefly, IVIG was injected unilaterally (200 $\mu \mathrm{g}$ in the volume of $2 \mu \mathrm{l}$ ) into the hippocampi of 16 -month-old APP/PS1 mice. The animals were transcardially perfused 3 days later, and the brains were applied to immunohistochemistry.

\section{Immunohistochemistry}

At the end of the study the mice were anesthetized with an anesthetics cocktail consisting of $105 \mathrm{mg} / \mathrm{kg}$ pentobarbiturate and $425 \mathrm{mg} / \mathrm{kg}$ chloral hydrate, and transcardially perfused with heparinized saline. Brains were retrieved rapidly and immersion fixed in $4 \%$ 
paraformaldehyde in $0.1 \mathrm{M} \mathrm{PB}$ for $4 \mathrm{~h}$, moved to $30 \%$ sucrose in $0.1 \mathrm{M}$ PB overnight and stored at $-70^{\circ} \mathrm{C}$ until further processed. Coronal brain sections, $35 \mu \mathrm{m}$ in thickness, were cut with a freezing-sliding microtome at the level of the septal (dorsal) hippocampus. For human IgG staining the sections were treated with $0.1 \% \mathrm{H}_{2} \mathrm{O}_{2}$ in methanol, and incubated overnight with rabbit anti-human HRP-labelled Ab (DAKO, 1:7500 in TBS containing $0.25 \%$ Triton X-100 (TBS-T), pH 7.6. Immunoreactivity was visualized with $\mathrm{H}_{2} \mathrm{O}_{2}$ and $0.25 \%$ nickel enhanced diaminobenzidine (Sigma).

For triple staining to study co-localization of $A \beta$, microglia and human IgG, free floating sections were extensively washed with $0.1 \mathrm{M}$ TBS, pH 7.4 and nonspecific binding sites in the tissue were blocked with $5 \%$ normal donkey serum in TBS, to which $0.3 \%$ Triton X100 had been added (NDS-TBS-T), for $1 \mathrm{~h}$. The sections were then incubated overnight with a mixture of biotinylated monoclonal mouse anti-A $\beta 17-24$ (clone 4G8, Covance, 1:100 in NDS-TBS-T) and rabbit-anti-Iba 1 (Wako Chemicals GmbH, Neuss, Germany, 1:400). Next, the sections were rinsed with TBS and applied to a cocktail of highly purified, carbocyanine (Cy)-conjugated secondary Abs (all from Jackson ImmunoResearch, West Grove, PA, $20 \mu \mathrm{g} / \mathrm{ml}$ in TBS containing $2 \%$ BSA): Cy3-coupled streptavidin, Cy5-coupled donkeyanti-rabbit IgG and Cy2-coupled donkey anti-human IgG. The sections were examined with a confocal laserscanning microscope (LSM10 Meta, Zeiss) as described before [48]. The Cy5-immunolabelling was color-coded in blue.

\section{Statistical analysis}

The data are expressed as mean \pm SD and were analyzed with SPSS software using Student's T-test or oneway ANOVA when appropriate, followed by Dunnett's or Tukey's post hoc test. * $(\mathrm{p}<0.05)$, ** $(\mathrm{p}<0.01)$, *** $(\mathrm{p}<0.001)$.

\section{Results}

IVIG protects primary hippocampal neurons against $A \beta 1$ 42 toxicity

When mouse hippocampal neuronal cultures containing $90 \%$ of neurons were exposed to 5 or $10 \mu \mathrm{M}$ oligomerrich $\mathrm{A} \beta 1-42$ preparation (Figure $1 \mathrm{~A}$ ) for $48 \mathrm{~h}$, significant neuronal death was observed by LDH release into the cytoplasm and by counting surviving neurons ( $\mathrm{p}<$ 0.001 , Figure $1 \mathrm{~B}$ and $1 \mathrm{C})$. Co-administration of $10 \mu \mathrm{M}$ IVIG reduced the toxicity of $10 \mu \mathrm{M} A \beta 1-42$, when LDH release was measured ( $\mathrm{p}<0.05$, Figure $1 \mathrm{~B})$, and $5 \mu \mathrm{M}$ IVIG completely blocked the toxicity of $5 \mu \mathrm{M} \mathrm{A} \beta 1-42$, when viable cell count was recorded ( $\mathrm{p}<0.001$, Figure $1 C)$. IVIG treatment alone posed no toxicity to primary neuronal cells (Figure $1 \mathrm{~B}$ ).
IVIG prevents $A \beta 1-42$ fibrillization to the same extent as irrelevant IgG and does not solubilize natively formed brain $A \boldsymbol{\beta}$ deposits

Potential mechanisms for IVIG-induced neuroprotection against $A \beta$-induced cell death include interaction of IVIG with $A \beta 1-42$ peptides by preventing oligomerization and further fibrillization of $A \beta 1-42$, or solubilization of pre-formed $A \beta 1-42$ fibrils/aggregates. When $A \beta 1-42$ was taken into aqueous solution, $A \beta 1-42$ started to oligomerize immediately, reaching a fully aggregated state after $48 \mathrm{~h}$ of incubation (Figure 1A) as we have also previously shown [44].

When $10 \mu \mathrm{M} A \beta 1-42$ was incubated in the presence of IVIG, fibrillization of $A \beta 1-42$ was reduced as determined with Thioflavin-T staining (Figure 1D). However, the effect of IVIG on A $\beta 1-42$ fibrillization was not concentration-dependent and did not differ from the effect of irrelevant human IgG. This suggests that the reduction of $A \beta 1-42$ fibrillization was not due to any specific immunoglobulins present in IVIG.

To test whether IVIG could solubilize natively formed human A $\beta$ deposits in brain, sections of aged APP/PS1 mouse brains were incubated with $20 \mu \mathrm{M}$ IVIG for seven days and the medium was collected for quantification of solubilized $A \beta 1-42$ with ELISA. In addition, the brain sections were analyzed for the possible reduction of $A \beta$ burden in the tissue by $A \beta$ immunostaining. We observed no effect of IVIG on the amount of $A \beta$ found in the media as an indicator of the solubilization of $\mathrm{A} \beta 1-42$ from the brain sections (Figure 1E) or on total $\mathrm{A} \beta$ burden in the brain sections (Figure 1F).

\section{IVIG specifically promotes microglia-mediated clearance of brain $A \beta$}

When microglia were applied on top of unfixed cryostat-cut brain sections prepared from aged APP/PS1 mice, and $A \beta$ burden was quantified as $A \beta$ immunoreactivity covering the hippocampal area of the brain section, we observed a reduction of human $A \beta$ burden to $86 \%$ when compared to control sections ( $p<0.05$, Figure $2 \mathrm{~A}$ and $2 \mathrm{C}$ ). The analysis was focused on hippocampal brain areas of the brain sections due to regionspecific and even distribution of human $A \beta$ within those areas, making comparisons between the sections feasible. Twenty micromolar IVIG further promoted the ability of microglia to reduce $A \beta$ burden to $68 \%$ from that of control sections $(\mathrm{p}<0.05)$ (Figure $2 \mathrm{~A}$ and $2 \mathrm{C})$. Based on the co-localization of $A \beta$ immunoreactivity and DAPI nuclear staining, the reduction of $A \beta$ was also seen as $A \beta$-free cavities in the brain sections at sites of cultured microglia cell bodies (Figure 1D). IVIG per se did not interfere with the subsequent detection of $A \beta$ immunoreactivity (total $\mathrm{A} \beta$ burden $11.3 \pm 0.8 \%$ in control and $10.8 \pm 1.1 \%$ in $20 \mu \mathrm{M}$ IVIG treated sections, 


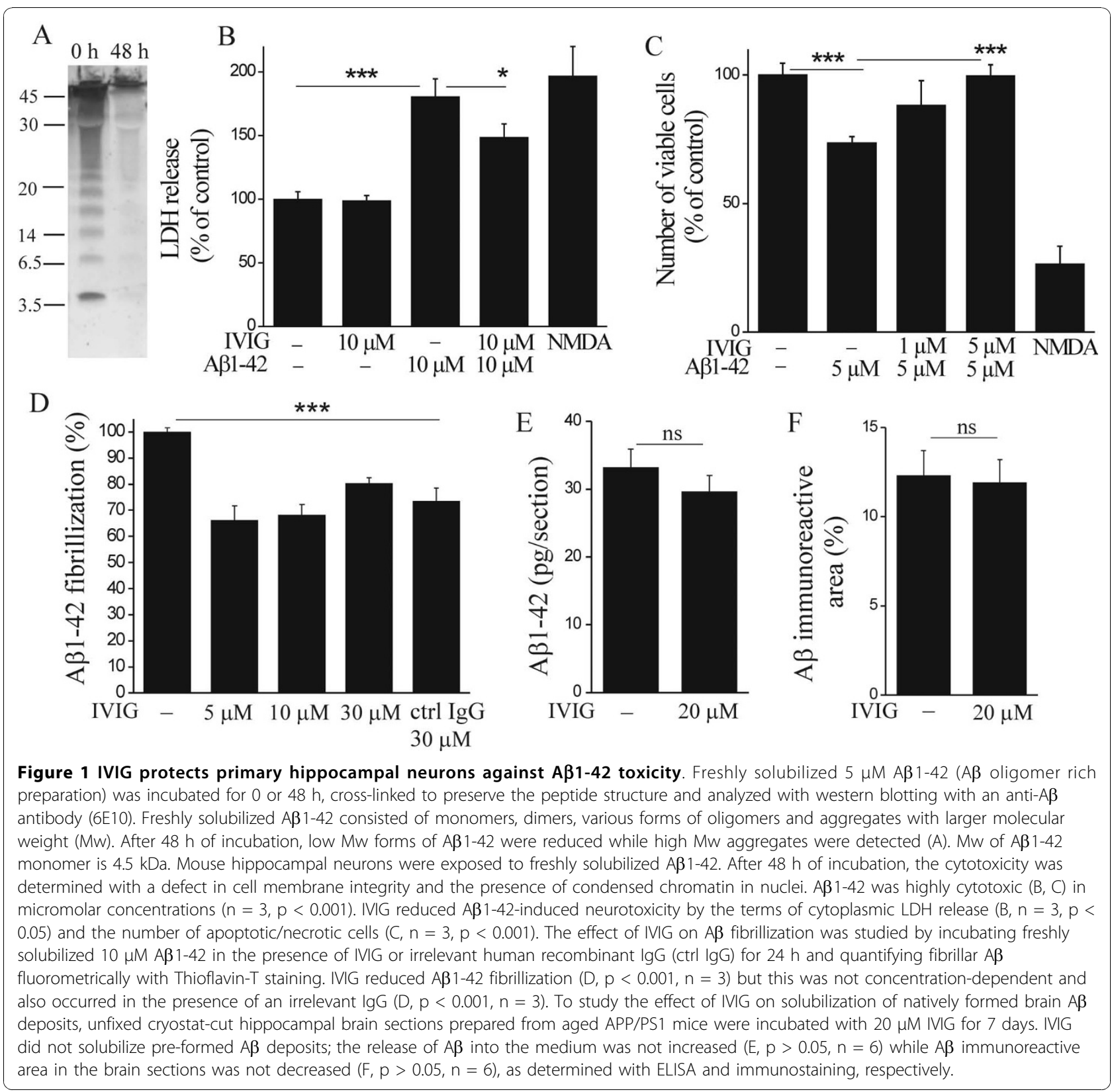

$p>0.05$ ), confirming that the reduction of $A \beta$ immunoreactivity indeed represents the reduction of $A \beta$ burden in the brain tissue.

Primary astrocytes obtained from adult but not neonatal mouse brain has been shown to participate in the removal of $A \beta$ from the brain [16]. When the ex vivo assay was performed with adult mouse astrocytes, a significant reduction of $A \beta$ burden to $86 \%$ of control (Figure 2B p $<0.01$ ) was observed, as previously described [15]. However, IVIG up to $20 \mu \mathrm{M}$ concentration did not promote the astrocyte-mediated $A \beta$ clearance (Figure $2 \mathrm{~B}$ ). The inability of IVIG to enhance astrocyte-mediated $A \beta$ clearance was not due to prevention of astrocyte clustering which has been previously shown [15] to be required for $A \beta$ clearance by these cells (data not shown).

The microglia-mediated reduction in brain $\mathrm{A} \beta$ burden was more evident in regions containing the highest amount of $\mathrm{A} \beta$-immunoreactive material, particularly in the subiculum, which showed accumulation of both diffuse and more dense $A \beta$ deposits. Quantifying immunoreactivity in the subiculum, we observed that microglia reduced $A \beta$ burden to $73 \%$ of control sections ( $p<0.05$, Figure $3 \mathrm{~A}$ ). Twenty micromolar IVIG further promoted the microglia-mediated reduction of $A \beta$ burden to $47 \%$ $(p<0.05$, Figure $3 \mathrm{~A})$. The reduction of $\mathrm{A} \beta$ was also 


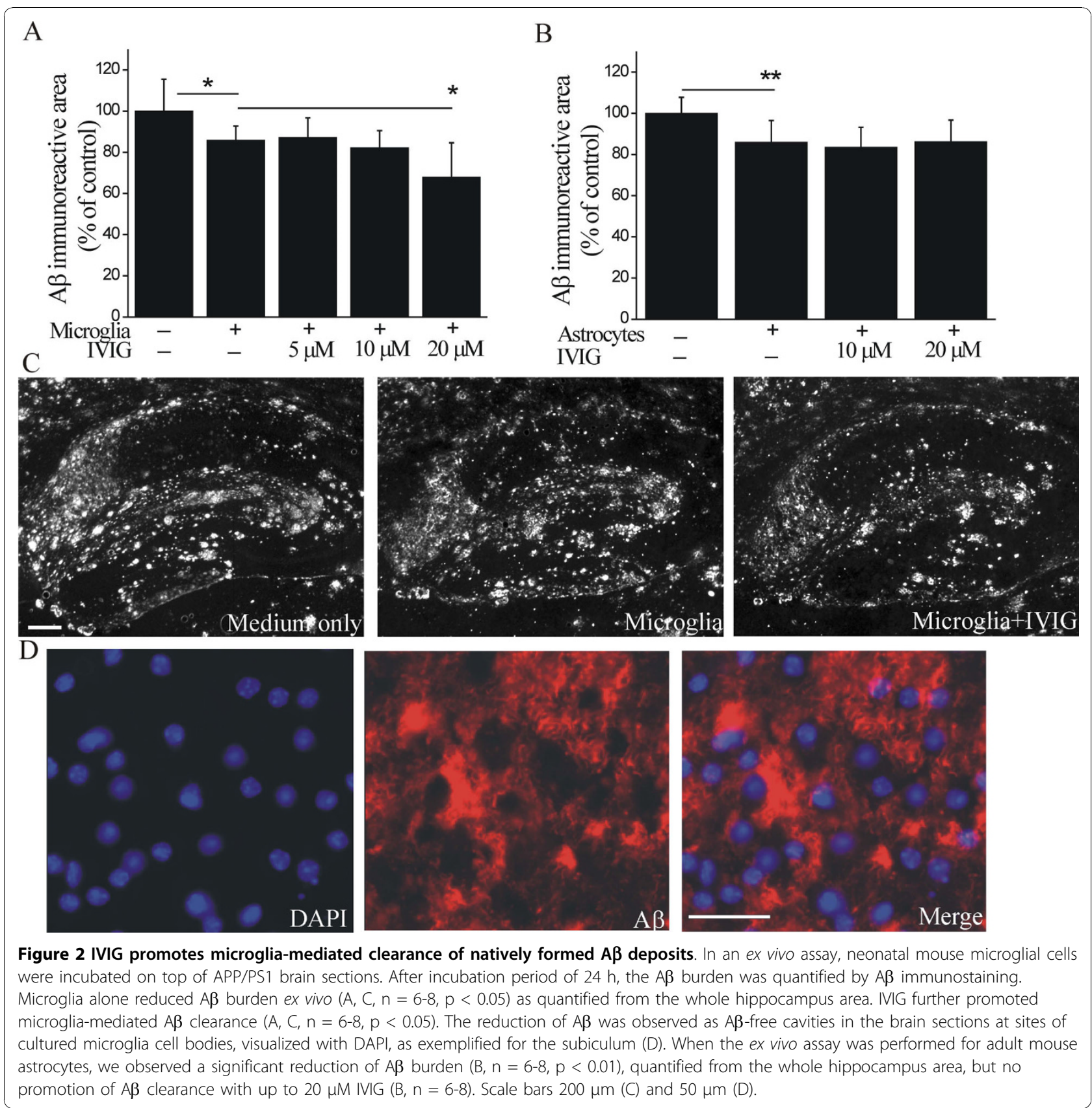

observed as $A \beta$-free cavities in the sections at sites of microglia cell bodies (Figure 3B). Furthermore, we discovered that diffuse $A \beta$ immunoreactivity was greatly reduced and nearly disappeared when incubated in the presence of microglia and $20 \mu \mathrm{M}$ IVIG (Figure 3B).

To exclude the possibility that IVIG induced microglia proliferation and thereby enhanced microglia-mediated clearance of $A \beta$, we counted the microglia cells at the 24 $\mathrm{h}$ time point (data not shown) at the end of the ex vivo assay from images taken exactly from the same site of the brain section that was used to quantify $\mathrm{A} \beta$ clearance. The enhanced clearance of $A \beta$ was not due to the increased number of microglia in response to IVIG. Moreover, IVIG had no effect on cell viability as studied with resazurin assay measuring cellular metabolism (Figure 3C).

Mechanisms of microglia-mediated clearance of brain $A \beta$ We next examined whether the effect of IVIG on $A \beta$ clearance was dependent on anti-A $\beta$ Abs present in IVIG. The ex vivo assay was therefore performed in the presence of IVIG depleted for A $\beta$ Abs (depleted IVIG). Microglia were able to reduce $A \beta$ burden in the presence of IVIG 


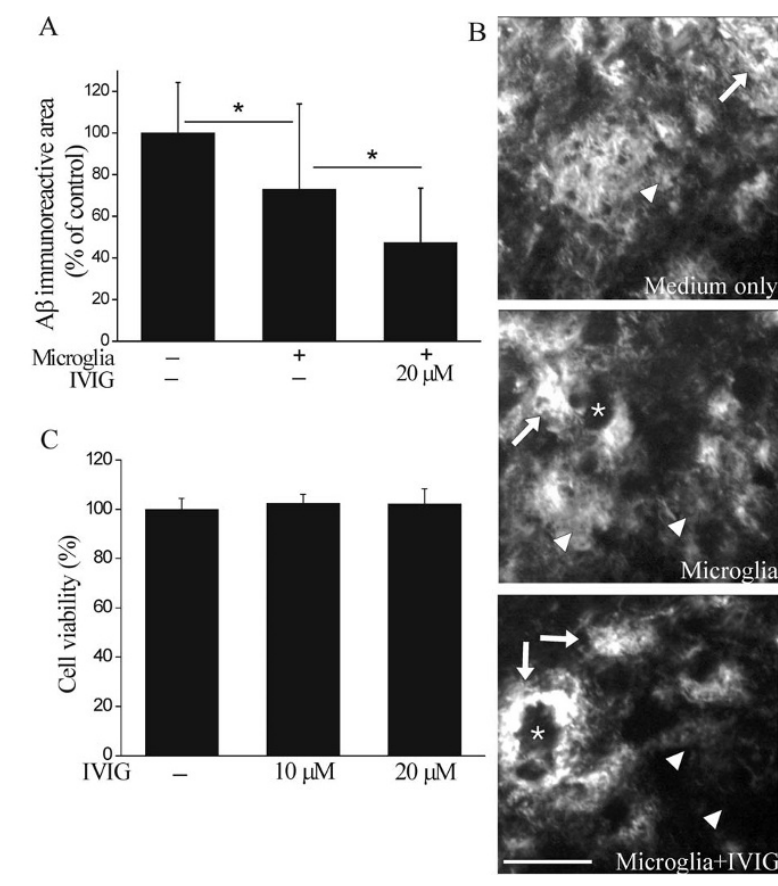

Figure 3 IVIG promotes miroglia-mediated clearance of diffuse $\mathbf{A} \boldsymbol{\beta}$ deposits. Within the hippocampus the microglia-mediated reduction in $A \beta$ burden was the most evident in the subiculum which displayed both dense (arrows) and diffuse (arrowheads) A $\beta$ deposition (B). We observed primary microglia to reduce $A \beta$ burden from the subiculum ( $A, n=15, p<0.05)$. IVIG further promoted the microglia-mediated clearance of $A \beta(A, n=15, p<0.05)$. Diffuse $A \beta$ deposits (arrowheads) were greatly reduced and nearly disappeared when incubated in the presence of microglia and $20 \mu \mathrm{M}$ IVIG (B). $A \beta$-free cavities, present in the brain sections incubated with microglia or microglia and IVIG, are shown with asterisks $\left(^{*}\right)$. IVIG did not affect cell proliferation or viability as measured with cellular metabolic activity (C). Scale bar $50 \mu \mathrm{m}$

and depleted IVIG to $26 \%(\mathrm{p}<0.001)$ and $62 \%(\mathrm{p}<0.05)$ of control, respectively (Figure $4 \mathrm{~A}$ and $4 \mathrm{~B}$ ). However, the microglia-mediated clearance of $A \beta$ was significantly diminished $(\mathrm{p}<0.05)$ in the presence of depleted IVIG in comparison to IVIG, suggesting that $A \beta$ Abs present in IVIG are further promoting $A \beta$ clearance (Figure $4 \mathrm{~A}$ ). To reveal whether binding of certain components of IVIG preparation was enough to induce enhanced $A \beta$ clearance by microglia, the pre-incubation of brain sections with IVIG was followed by wash out of any unbound IVIG prior to addition of microglia reduced $A \beta$ burden to $44 \%$ $(\mathrm{p}<0.001)$ of control (Figure 4A). In addition, following IVIG wash out microglia did not significantly differ from IVIG-treated microglia in their capacity to reduce $A \beta$ burden. These results suggest that interaction of IVIG with $A \beta$ deposits may be sufficient to promote $A \beta$ clearance by microglia (Figure 4A and 4B).

To study the role of lysosomal degradation in microglia-mediated $\mathrm{A} \beta$ clearance, we performed the ex vivo assay in the presence of Baf, an inhibitor of vacuolar $\mathrm{H}^{+}$ ATPase (V-ATPase). Baf disrupts the lysosomal membrane proton pump that maintains the low intralysosomal $\mathrm{pH}$ needed for normal lysosomal activity [49]. In the presence of both Baf and microglia, $A \beta$ deposits remained mostly intact showing that intralysosomal $\mathrm{pH}$ and anticipated inactivation of lysosomal proteases by Baf prevented the ability of microglia to clear brain $A \beta$ ( $p>0.05$, Figure 5A and 5B). IVIG was partially able to restore microglia-mediated $\mathrm{A} \beta$ clearance halted by $\mathrm{Baf}$ as IVIG-enhanced microglia-mediated clearance of $A \beta$ did not significantly decay when Baf was administered ( $p>0.05$, Figure 5A). In the presence of Baf, IVIG enhanced microglia-mediated $A \beta$ clearance predominantly from the sites of diffuse $A \beta$ deposits (Figure $5 B$ ). These results suggest that the IVIG-enhanced $A \beta$ clearance involves $A \beta$ uptake by microglia and is dependent on intracellular lysosomal degradation.

\section{IVIG penetrates into the brain and specifically binds $A \beta$ deposits}

Finally, we tested whether the cellular mechanisms of $A \beta$ clearance observed in vitro have potential relevance in vivo and dosed a few APP/PS1 mice i.p with IVIG or saline starting at the age of 4 months. The concern was whether human IVIG is able to cross the BBB to reach brain parenchyma in effective concentrations. After transcardial perfusion with saline to abolish any possible interference with IVIG present in the blood, the IVIG was identified from mouse brain sections with antihuman IgG. IVIG penetrated the BBB as evidenced with intensive anti-human IgG staining in the mouse hippocampus (Figure 6A). There was a clear anterior-posterior gradient with the highest immunoreactivity at the septal end of the hippocampus adjacent to the choroid plexus. In addition, strong immunoreactivity was observed lining the ventricles (Figure 6A). The intensity of anti-human IgG immunoreactivity increased with the duration of IVIG treatment (Figure 6C). Human IgG immunolabeling was also observed in wild-type mice, but to a lesser extent, suggesting that the BBB is more leaky in APP/PS1 mice (data not shown). When few APP/PS1 mice were injected with IVIG i.v., stronger immunoreactivity was detected in the hippocampus than after i.p. administration, suggesting that a higher concentration of IVIG available in the blood leads into a higher rate of penetration through the $\mathrm{BBB}$, favoring the i.v. administration route (data not shown).

In the hippocampus, $A \beta$ deposits appeared as stippled patterns of aggregated material covered with human IgG immunoreactivity (Figure 6D), which was not observed in IVIG treated wild type mice. When IVIG was injected directly into the hippocampus, homogenous IgG immunoreactivity was observed (Figure 6E) similar to the IgG 


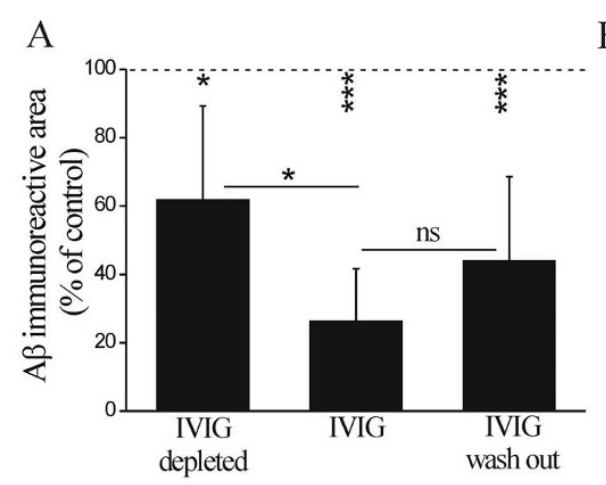

B
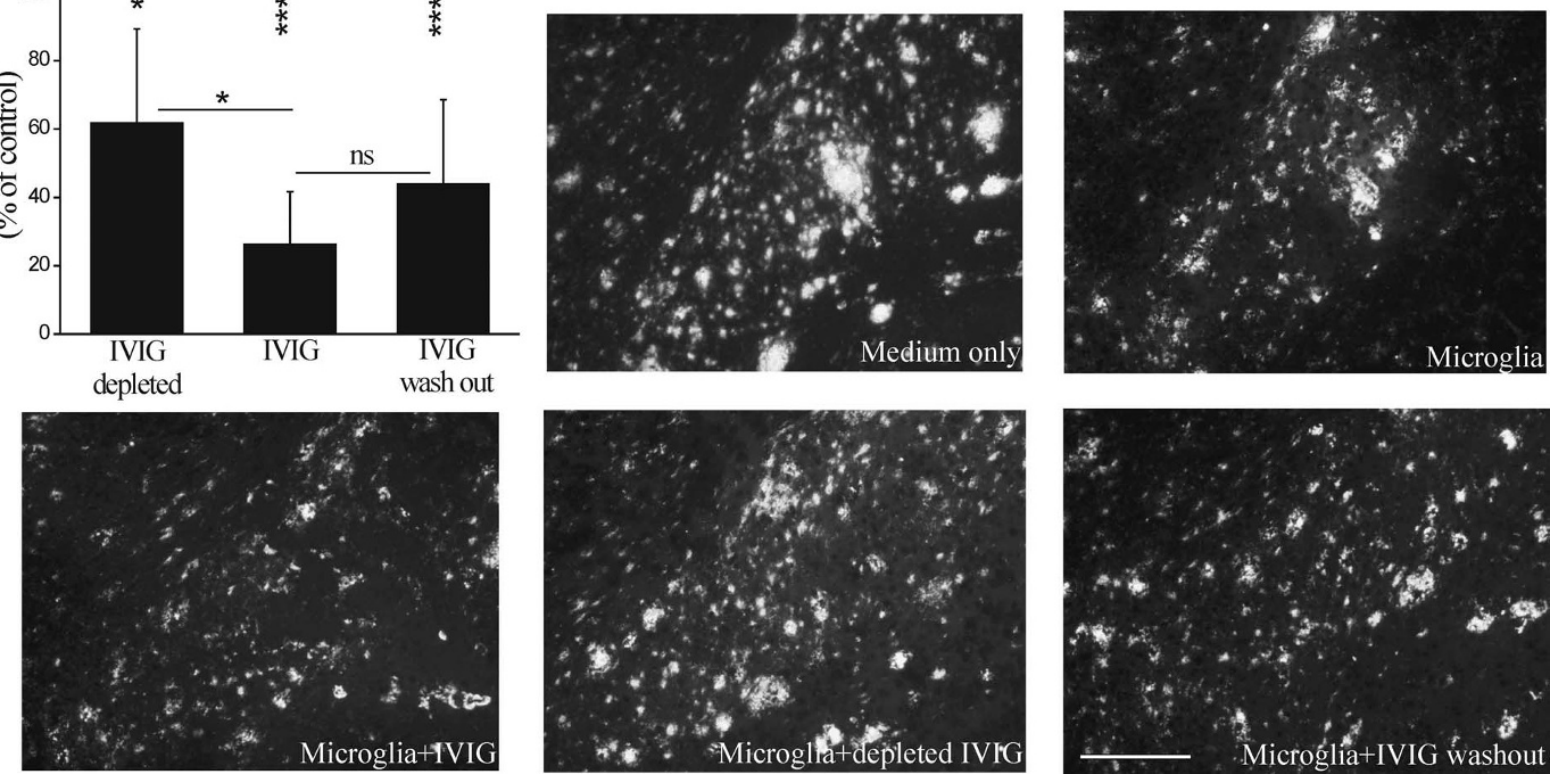

Figure $\mathbf{4}$ Promotion of microglia-mediated clearance of $\mathbf{A} \boldsymbol{\beta}$ is dependent on $\mathbf{A} \boldsymbol{\beta}$ antibodies in IVIG. The depletion of $A \boldsymbol{\beta}$ antibodies from IVIG significantly compromised the IVIG-promoted microglia-mediated $A \beta$ clearance $(A, n=5-6, p<0.05)$ as imaged in the subiculum (B). Preincubation of brain sections with $20 \mu \mathrm{M}$ IVIG followed by wash out of any unbound IVIG prior to addition of exogenous primary microglia conserved microglia-mediated $A \beta$ clearance $(A, B, n=5-6, p<0.001)$ that did not significantly differ from the ex vivo incubation in the presence of IVIG throughout the assay ( $n=5-6, p>0.05)$. Dotted line represents the $A \beta$ immunoreactive area in intact hippocampal brain sections incubated without microglia. The statistical significance of $A \beta$ clearance in comparison to intact brain section incubated without microglia is shown as asterisks below the dotted line, indicating the respective p-values. Scale bar $100 \mu \mathrm{m}$.

immunoreactivity observed after the peripheral IVIG administration (Figure 6A). After the local intrahippocampal injection, IgG immunoreactivity was defined within the injected brain hemisphere and IgG immunoreactivity was not observed lining the ventricles (Figure 6E). After intrahippocampal injection, IVIG appeared as stippled patterns of aggregated material covered with human IgG immunoreactivity (Figure 6E). Some human IgG immunoreactive spots were also positive for Congo Red staining, as a label for $\beta$-sheet structures in dense core $A \beta$ deposits (data not shown). Finally, we verified whether IVIG interacts with brain deposits of human-type $A \beta$ in transgenic mice after peripheral administration of IVIG. A closer examination with confocal microscopy revealed co-localization of human IgG and $A \beta$ deposits (Figure 7A, B and 7D), surrounded by increased number of microglia (Figure 7C and 7D). Very low levels of IVIG in areas devoid of $A \beta$ suggests a highly specific interaction of IVIG with $\mathrm{A} \beta$ deposits in vivo.

\section{Discussion}

IVIG has been proposed as a potential therapy for AD and it has recently been shown to alleviate AD pathology in an 18-month study carried out with 8 patients with mild AD [29]. However, the exact mechanism how
IVIG treatment may improve the AD pathology is unclear. Our study demonstrates that - in addition to neuroprotection towards $A \beta$ toxicity - IVIG enhances microglia-mediated but not astrocyte-mediated $A \beta$ clearance. Immunoglobulins in general seem to reduce $A \beta$ toxicity, and this beneficial effect is significantly enhanced by $A \beta$ specific Abs. We demonstrate that peripherally administered IVIG penetrates into the brain of transgenic mice mimicking human $\mathrm{AD}$ pathology and selectively binds to $A \beta$ deposits in the brain parenchyma. A $\beta$ deposits co-localized with IVIG are also tightly surrounded with Iba-1 positive microglia, demonstrating notable relevance in vivo.

The accumulation of $A \beta$ within the brain of $A D$ patients reflects an imbalance between the deposition of $\mathrm{A} \beta$ and its clearance from the brain parenchyma, leading to pathological events including neurotoxicity and inflammation. We performed neurotoxicity studies with freshly solubilized $A \beta 1-42$, modeling $A \beta$ toxicity in the presence of $A \beta$ oligomers and fibrils, as we and others have described before $[44,50]$. IVIG or purified $A \beta$ Abs of IVIG have been shown to inhibit neurotoxicity induced by $A \beta$ oligomers in rat cortical neurons [39] and N2A secondary cells [51]. We demonstrate IVIG to reduce $A \beta 1-42$ induced neurotoxicity in primary mouse 

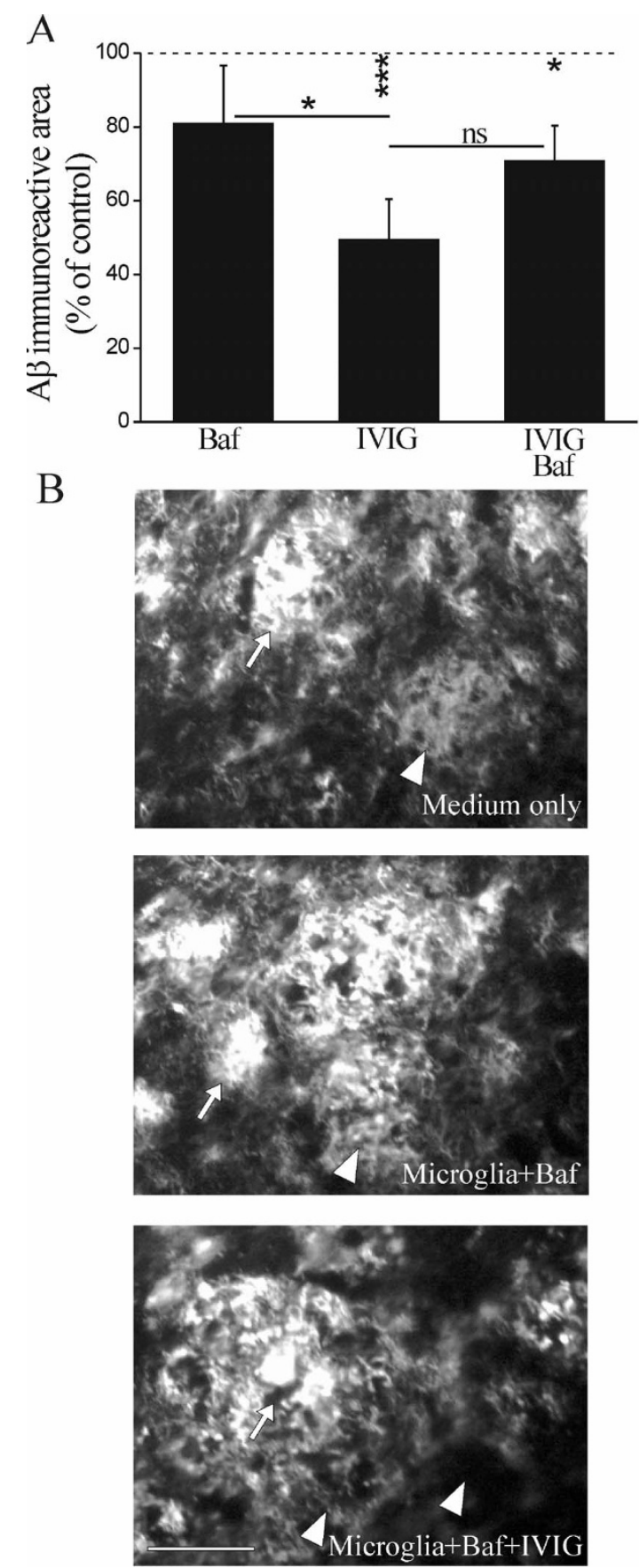

Figure 5 Promotion of microglia-mediated clearance of $A \beta$ is dependent on lysosomal degradation. To study the role of lysosomal degradation in microglia-mediated $A \beta$ clearance, the ex vivo assay was performed in the presence of Baf, an inhibitor of lysosomal degradation pathway. Baf inhibited microglia-mediated $A \beta$ clearance $(A, n=3-6)$ as $A \beta$ deposits remained mostly intact in sections treated with Baf (B). IVIG could partially restore microgliamediated $A \beta$ clearance halted by Baf. In the presence of Baf, $20 \mu \mathrm{M}$ IVIG treatment resulted in low clearance and mostly of diffuse $A \beta$ deposits only (A, B, n = 3-4, p < 0.05). Dense (arrows) and diffuse (arrowheads) $A \beta$ deposits are shown in the subiculum. Scale bar 50 $\mu \mathrm{m}$. neuronal cells cultured from the hippocampus, a brain area typically affected in AD. Britschgi et al. [34] reported that IgG purified from an individual AD patient or a healthy non-demented control reduced $A \beta$ neurotoxicity in a similar manner.

$\mathrm{A} \beta$ deposits are reduced in transgenic mouse models of $\mathrm{AD}$ via several mechanisms: (i) the inhibition of $\mathrm{A} \beta$ fibrillization by $A b$ binding to $A \beta$ [26,52], (ii) glial cell mediated clearance of $A \beta$, including microglia-mediated phagocytosis of opsonized $A \beta$ deposits $[13,21,53]$, and (iii) the peripheral sink route in which $A \beta$ Abs in the plasma extract $A \beta$ via equilibrium into the efflux of $A \beta$ across the $B B B$ [14]. It should be noted here, that different origin of IVIG preparations may account for binding of $A \beta$ species to varying extent $[54,55]$ causing a possible source of variation between different studies. Abs purified from IVIG have been shown in vitro to inhibit the fibrillization as well as to dissolve the preformed fibrils of $A \beta 25-35, A \beta 1$ 40 and $A \beta 1-42$ [39]. In addition, IVIG itself without further purification steps was shown to dissolve preformed $A \beta 1-40$ fibrils [39]. We have widely used an $A \beta 1$ 42 oligomerization and fibrillization model in our previous A $\beta$ neurotoxicity studies $[44,56,57]$. Utilizing this model, we observed IVIG to modestly reduce synthetic A $\beta 1-42$ fibrillization as detected with Thioflavin-T stain. This finding is in line with previous studies with IVIG in A $\beta 1-42$ fibrillization [39]. However, we found this was not due to any specific components present in IVIG since it also occurred upon application of an irrelevant human recombinant control $\mathrm{Ab}$, suggesting a mechanism independent of $A \beta$ Abs and possibly partly characteristic to Ab fragments in general. Furthermore, we observed no effect of IVIG on solubilization of natively formed human A $\beta$ deposits from APP/PS1 mouse brain sections. Besides detecting no solubilization of $A \beta$ into the medium, we observed no effect of IVIG on A $\beta$ burden quantified from APP/PS1 mouse brain sections either. Since IVIG had no additional effect on $A \beta 1-42$ fibrillization when compared to irrelevant IgG, we suggest IVIG to have a direct effect on neuronal cells to reduce $A \beta 1-42$ toxicity, or indirect protection via neutralization of $\mathrm{A} \beta 1-42$.

IVIG has previously been shown to enhance the uptake of exogenously provided fibrillar $\mathrm{A} \beta$ in $\mathrm{BV}-2$ cells, a secondary cell line model for microglia [40]. Instead of determining $A \beta$ uptake, we investigated the phagocytosis of $\mathrm{A} \beta$ by primary mouse microglia in an $e x$ vivo assay, where the clearance of natively deposited brain $A \beta$ was studied. The clearance of $A \beta$ by primary microglia has been shown to occur predominantly after opsonization of $A \beta$ deposits requiring their decoration with Abs for consequent recognition by microglia $[10-14,21]$. We found primary microglia to reduce $A \beta$ burden without any preceding opsonization step required. Moreover, we discovered IVIG to further 


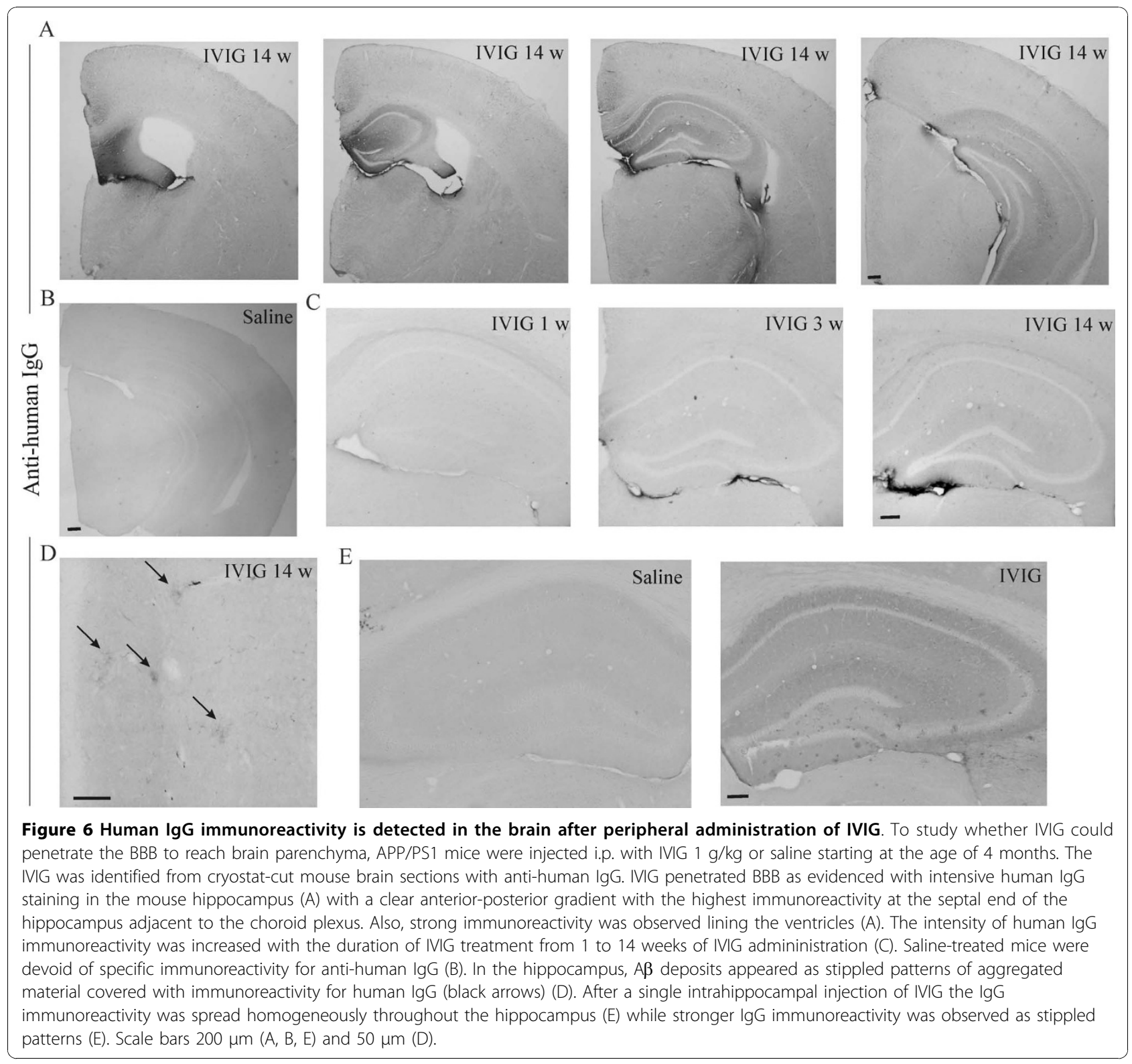

enhance the clearance of $A \beta$ deposits in a dose-dependent manner. In addition, the pre-treatment of brain sections with IVIG and wash-out of unbound IVIG before application of microglia was sufficient to enhance the clearance of $A \beta$ deposits. This suggests that interaction of IVIG with the $A \beta$ deposits may be sufficient to promote $A \beta$ clearance by microglia. Furthermore, the microglia-mediated clearance of $A \beta$ was significantly reduced in the presence of depleted IVIG in comparison to IVIG, suggesting that $A \beta$ Abs present in IVIG participated in $A \beta$ clearance. The ability of IVIG to induce promotion of $A \beta$ clearance appears to be specific for primary microglia, since we found no further enhancement of $A \beta$ clearance by primary astrocytes.
Reduction of diffuse $A \beta$ deposits occurred at sites of microglial cell body, where cavities in layers of human $\mathrm{A} \beta$ were seen to form. This phenomenon resembled "moth-eaten" A $\beta$ plaques previously described in vivo [58] showing special characteristics of microgliamediated $A \beta$ clearance. Earlier reports suggest that microglia express proteases such as MMPs which could degrade A $\beta$ extracellularly [59-61] and that IVIG induces expression of MMP-9 in microglia [62]. When ex vivo brain sections were incubated in the presence of microglia-conditioned and microglia plus IVIG-conditioned medium, we observed no significant reduction of brain $A \beta$ burden (data not shown), suggesting that extracellular proteases secreted by microglia were not 

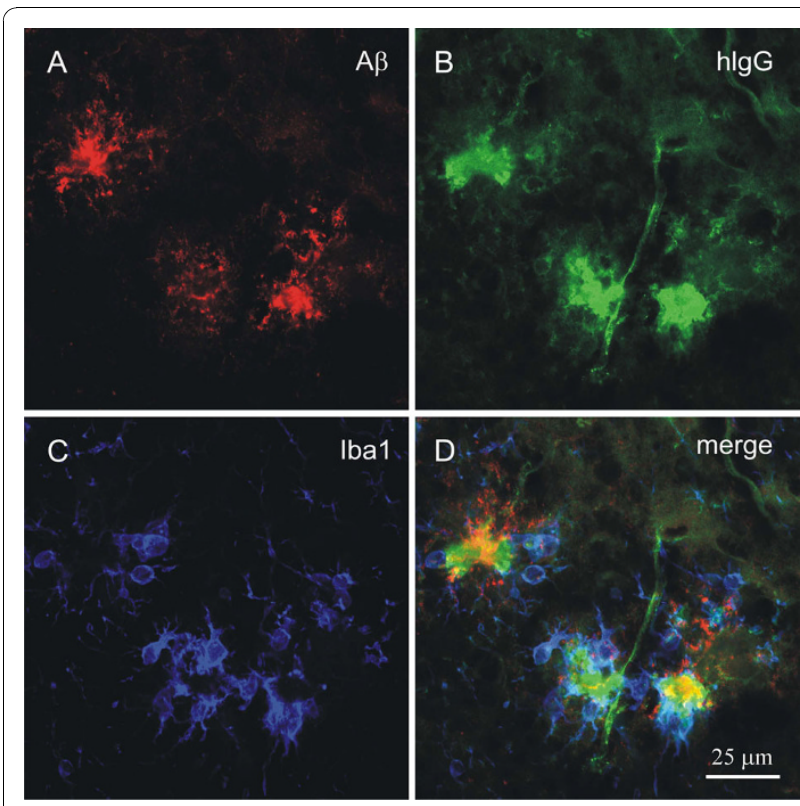

Figure 7 IVIG interacts with human-type $A \beta$ brain deposits in APP/PS1 mouse brain after peripheral administration. Triple immunofluorescence labelling of $A \beta$ deposits, human $\lg G$ and microglia was performed after peripheral i.p. administration of IVIG. $A \beta$-immunoreactive deposits (A) and human $\lg G(B)$ was observed to co-localize in the brain parenchyma, as revealed by confocal laser-scanning microscopy imaged in the lateral entorhinal cortex (D). Human IgG was detected predominantly within $A \beta$ plaques, but also in blood vessels (B). Human lgG-bound A $\beta$ deposits were surrounded by Iba-1 positive microglia (C, D). Merging the immunosignals in (D) indicates that $A \beta$ deposits were targeted both by human $\lg G$ and recruited microglia. The omission of primary antibodies resulted in the expected absence of immunolabelling.

the primarily responsible for IVIG-enhanced microgliamediated $A \beta$ clearance.

Cultured microglia have been shown to internalize $A \beta$ and deliver it to lysosomes [63] where most non-selective protein degradation takes place. Baf, an inhibitor of $\mathrm{V}$-ATPase, disrupts the maintenance of intralysosomal low $\mathrm{pH}$ [49]. We observed that $\mathrm{A} \beta$ deposits remained mostly intact in sections with Baf, indicating that intralysosomal $\mathrm{pH}$ and anticipated inactivation of lysosomal proteases by Baf affected the capability of microglia to clear A $\beta$. However, even in the presence of Baf, IVIG treatment resulted in microglia-mediated clearance mostly from diffuse $A \beta$ deposits, suggesting that IVIG may potentiate microglia-mediated $A \beta$ clearance by counteracting lysosomal deficits in microglia. In addition, inactivated microglia have weakly acidic lysosomes, and lysosomal acidification during activation of microglia is required for $A \beta$ degradation by microglia [64]. Thus our results suggest that $A \beta$ clearance occurs by lysosomal degradation and boosting the lysosomal activity of microglia, potentially by IVIG, could increase A $\beta$ clearance.
Recently, a receptor for anti-inflammatory activity of IVIG was identified. Sialylated IgG Fc fragments in IVIG were demonstrated to bind to SIGN-R1, a receptor on mouse splenocytes, resulting in secretion of soluble antiinflammatory mediators that regulate macrophage activity [65]. However, since our model based on isolated microglia from the CNS, this is not likely the mechanism for IVIG activity. Generally, IVIG has been proposed to regulate the activating and inhibitory $\mathrm{F} c \gamma \mathrm{R}$ on macrophages to modulate inflammation [27]. Since the Fc $\gamma R$-mediated effect would rather suppress the inflammatory pathways, including phagocytosis, this is not likely the mechanism explaining the IVIG-enhanced phagocytosis in microglia. In the presence of IVIG, BV2 microglia display ramified morphology with high expression of activation marker CD45, suggesting that IVIG induces a specific activation pattern on microglia [40]. Furthermore, it has been shown that intracranial $\mathrm{A} \beta \mathrm{Ab}$ administration leads into a biphasic clearance of $A \beta$ deposits [66]; first a rapid removal of diffuse $A \beta$ deposits, and second the removal of compact $A \beta$ deposits associated with a transient activation of microglia. We found IVIG to enhance microglia-mediated clearance of diffuse $A \beta$ largely dependent on $A \beta$ Abs.

Unmodified immunoglobulins show a low tendency to penetrate through the BBB [67], but in certain conditions such as specific stages of diseases and in senescence, immunoglobulins have easier access into the brain $[13,68]$. Natural Abs recognizing oligomeric $A \beta$ assemblies have been found to reside in the human cerebrospinal fluid, but at 30-230 times lower concentration than in plasma but the repertoires of IgG Abs are the same in these two compartment [34]. IgG has been shown to bind to $A \beta$ deposits in brain in $A D$ patients while a high IgG plaque labeling index was accompanied with reduced plaque burden suggesting that auto-Abs against $A \beta$ may help to control $A \beta$ burden [35]. Whether administration of IVIG, as a therapy, could further increase plaque labeling in patients with high IgG plaque labeling index or compensate reduced plaque labeling in patiens with low IgG plaque labeling index to further enhance the recognition and phagocytosis of $A \beta$ deposits remains to be clarified. As presented here, we studied the penetration of peripherally administered exogenous IVIG into the brain and binding to $A \beta$ deposits. By injecting human IgG into a mouse, we had the opportunity to visualize the distribution of IVIG in the mouse brain. We found that peripherally administered IVIG reached the brain parenchyma with sufficient concentrations to be detected, but that also significant regional differences existed. The highest concentration of human IgG was found in the septal hippocampus with a clear declining gradient toward the temporal end of this brain structure. Together with strong IgG 
immunoreactivity lining the ventricles, this finding indicates that the primary access route of IVIG to the mouse brain is through the choroid plexus.

To demonstrate the relevance of these findings in vivo, we found peripherally administered IVIG to bind to A $\beta$ deposits in the brain parenchyma. Human IgG-bound $\mathrm{A} \beta$ deposits were accompanied by closely surrounding Iba-1 immunoreactive microglia. This suggests that IVIG not only can bind to soluble oligomeric $A \beta$ species and potentially prevent $A \beta$ fibrillization and toxicity, but IVIG can also bind to pre-formed $\mathrm{A} \beta$ deposits in vivo and possibly contribute to reduction of $A \beta$ burden after initial $\mathrm{A} \beta$ deposition. As supported by our ex vivo data, surrounding microglia may also contribute to $A \beta$ clearance after IVIG administration in vivo.

\section{Conclusions}

The present data demonstrate that in addition to neuroprotective effects, IVIG promotes recognition and removal of natively formed human $A \beta$ deposits by microglia. Our results suggest that natural $A \beta$ Abs in IVIG interact with and promote the phagocytosis of $A \beta$ deposits, resulting in enhanced microglia-mediated $A \beta$ clearance. This has therapeutic relevance in vivo as we found that peripherally administered IVIG penetrates through the $\mathrm{BBB}$ and specifically binds to $\mathrm{A} \beta$ deposits in the brain parenchyma. These findings strongly support IVIG as a potential therapy to compensate the deprivation of naturally occurring $A \beta$ Abs in $A D$ that could alleviate the $A \beta$-induced toxicity.

\footnotetext{
Acknowledgements

We thank Dr D. Borchelt and J. Jankowsky for the APP/PS1 colony founders. We thank Laila Kaskela, Mirka Tikkanen and Pasi Miettinen (University of Eastern Finland) for valuable technical assistance with primary cell cultures, biochemical analysis and immunohistochemistry. We also thank Ute Bauer (University of Leipzig) for excellent technical assistance with triple immunofluorescence labeling. Finally, we thank Elisabeth Maier, Birgit Reipert and Hans-Peter Schwarz for their extensive scientific expertise utilized in the design and implementation of this study.

This work was supported by Academy of Finland.
}

\section{Author details}

'Department of Neurobiology, A. I. Virtanen Institute for Molecular Sciences, University of Eastern Finland, Kuopio, Finland. ${ }^{2}$ Paul Flechsig Institute for Brain Research, University of Leipzig, Leipzig, Germany. ${ }^{3}$ Department of Neurology, Kuopio University Hospital, Kuopio, Finland. ${ }^{4}$ Department of Oncology, Kuopio University Hospital, Kuopio, Finland. ${ }^{5}$ School of Pharmacy, University of Eastern Finland, Kuopio, Finland. ${ }^{6}$ Medeia Therapeutics Ltd., Kuopio, Finland.

\section{Authors' contributions}

JM participated in the phagocytosis assays and statistical analysis and drafted the manuscript. RP and SN carried out the phagocytosis assays and participated in the data analysis. KK performed toxicity studies, participated in the data analysis and helped to draft the manuscript. GG carried out fibrillization experiments and participated in the interpretation of the data. LP and TM carried out in vivo experiments and participated in the data analysis and interpretation of the data. WH and JG carried out immunohistochemistry, confocal microscopy and interpretation of the data.
HT and JK participated in the design of the study and drafting and revising the manuscript. MK participated in the design of the study, data analysis and drafting and revising the manuscript. All authors read and approved the final manuscript.

\section{Competing interests}

The Principal Investigators J. Koistinaho and $\mathrm{H}$. Tanila have received funding from Baxter Innovations $\mathrm{GmbH}$ for their research projects in the University of Eastern Finland. All experiments and data analysis of this study were conducted in the University of Eastern Finland.

Received: 4 October 2010 Accepted: 7 December 2010

Published: 7 December 2010

\section{References}

1. Selkoe DJ: Alzheimer's disease: genes, proteins, and therapy. Physiol Rev 2001, 81:741-66.

2. Meyer-Luehmann M, Spires-Jones TL, Prada C, Garcia-Alloza M, de Calignon A, Rozkalne A, Koenigsknecht-Talboo J, Holtzman DM, Bacskai BJ, Hyman BT: Rapid appearance and local toxicity of amyloid-beta plaques in a mouse model of Alzheimer's disease. Nature 2008, 451:720-4.

3. Walsh DM, Klyubin I, Fadeeva JV, Cullen WK, Anwyl R, Wolfe MS, Rowan MJ, Selkoe DJ: Naturally secreted oligomers of amyloid beta protein potently inhibit hippocampal long-term potentiation in vivo. Nature 2002, 416:535-9.

4. Cleary JP, Walsh DM, Hofmeister Jנ, Shankar GM, Kuskowski MA, Selkoe Dر, Ashe $\mathrm{KH}$ : Natural oligomers of the amyloid-beta protein specifically disrupt cognitive function. Nat Neurosci 2005, 8:79-84.

5. Nimmerjahn A, Kirchhoff F, Helmchen F: Resting microglial cells are highly dynamic surveillants of brain parenchyma in vivo. Science 2005, 308:1314-8.

6. Glezer I, Simard AR, Rivest S: Neuroprotective role of the innate immune system by microglia. Neuroscience 2007, 147:867-83.

7. Fiala M, Cribbs DH, Rosenthal M, Bernard G: Phagocytosis of amyloid-beta and inflammation: two faces of innate immunity in Alzheimer's disease. J Alzheimers Dis 2007, 11:457-63.

8. El Khoury J, Toft M, Hickman SE, Means TK, Terada K, Geula C, Luster AD: Ccr2 deficiency impairs microglial accumulation and accelerates progression of Alzheimer-like disease. Nat Med 2007, 13:432-8.

9. Wyss-Coray T: Inflammation in Alzheimer disease: driving force, bystander or beneficial response? Nat Med 2006, 12:1005-15.

10. Schenk D, Barbour R, Dunn W, Gordon G, Grajeda H, Guido T, Hu K, Huang J, Johnson-Wood K, Khan K, Kholodenko D, Lee M, Liao Z, Lieberburg I, Motter R, Mutter L, Soriano F, Shopp G, Vasquez N, Vandevert C, Walker S, Wogulis M, Yednock T, Games D, Seubert P: Immunization with amyloid-beta attenuates Alzheimer-disease-like pathology in the PDAPP mouse. Nature 1999, 400:173-7.

11. Morgan D, Diamond DM, Gottschall PE, Ugen KE, Dickey C, Hardy J, Duff K Jantzen P, DiCarlo G, Wilcock D, Connor K, Hatcher J, Hope C, Gordon M, Arendash GW: Abeta peptide vaccination prevents memory loss in an animal model of Alzheimer's disease. Nature 2000, 408:982-5.

12. Janus C, Pearson J, McLaurin J, Mathews PM, Jiang Y, Schmidt SD, Chishti MA, Horne P, Heslin D, French J, Mount HT, Nixon RA, Mercken M, Bergeron C, Fraser PE, George-Hyslop P, Westaway D: Abeta peptide immunization reduces behavioural impairment and plaques in a model of Alzheimer's disease. Nature 2000, 408:979-82

13. Bard F, Cannon C, Barbour R, Burke RL, Games D, Grajeda H, Guido T, Hu K, Huang J, Johnson-Wood K, Khan K, Kholodenko D, Lee M, Lieberburg I, Motter R, Nguyen M, Soriano F, Vasquez N, Weiss K, Welch B, Seubert P, Schenk $D$, Yednock T: Peripherally administered antibodies against amyloid beta-peptide enter the central nervous system and reduce pathology in a mouse model of Alzheimer disease. Nat Med 2000 6:916-9.

14. DeMattos RB, Bales KR, Cummins DJ, Dodart JC, Paul SM, Holtzman DM: Peripheral anti-Abeta antibody alters CNS and plasma A beta clearance and decreases brain A beta burden in a mouse model of Alzheimer's disease. Proc Natl Acad Sci USA 2001, 98:8850-5.

15. Koistinaho M, Lin S, Wu X, Esterman M, Koger D, Hanson J, Higgs R, Liu F, Malkani S, Bales KR, Paul SM: Apolipoprotein E promotes astrocyte colocalization and degradation of deposited amyloid-beta peptides. Nat Med 2004, 10:719-26. 
16. Wyss-Coray T, Loike JD, Brionne TC, Lu E, Anankov R, Yan F, Silverstein SC, Husemann J: Adult mouse astrocytes degrade amyloid-beta in vitro and in situ. Nat Med 2003, 9:453-7.

17. Bolmont T, Haiss F, Eicke D, Radde R, Mathis CA, Klunk WE, Kohsaka S, Jucker M, Calhoun ME: Dynamics of the microglial/amyloid interaction indicate a role in plaque maintenance. J Neurosci 2008, 28:4283-92.

18. Rogers J, Strohmeyer R, Kovelowski CJ, Li R: Microglia and inflammatory mechanisms in the clearance of amyloid beta peptide. Glia 2002, 40:260-9.

19. D'Andrea MR, Cole GM, Ard MD: The microglial phagocytic role with specific plaque types in the Alzheimer disease brain. Neurobiol Aging 2004, 25:675-83

20. Floden AM, Combs CK: Beta-amyloid stimulates murine postnatal and adult microglia cultures in a unique manner. J Neurosci 2006, 26:4644-8.

21. Wilcock DM, Rojiani A, Rosenthal A, Levkowitz G, Subbarao S, Alamed J, Wilson D, Wilson N, Freeman MJ, Gordon MN, Morgan D: Passive amyloid immunotherapy clears amyloid and transiently activates microglia in a transgenic mouse model of amyloid deposition. J Neurosci 2004, 24:6144-51.

22. Dodart JC, Bales KR, Gannon KS, Greene SJ, DeMattos RB, Mathis C, DeLong CA, Wu S, Wu X, Holtzman DM, Paul SM: Immunization reverses memory deficits without reducing brain Abeta burden in Alzheimer's disease model. Nat Neurosci 2002, 5:452-7.

23. DeMattos RB, Bales KR, Cummins DJ, Paul SM, Holtzman DM: Brain to plasma amyloid-beta efflux: a measure of brain amyloid burden in a mouse model of Alzheimer's disease. Science 2002, 295:2264-7.

24. Pan W, Solomon B, Maness LM, Kastin AJ: Antibodies to beta-amyloid decrease the blood-to-brain transfer of beta-amyloid peptide. Exp Biol Med (Maywood) 2002, 227:609-15

25. Deane R, Sagare A, Hamm K, Parisi M, LaRue B, Guo H, Wu Z, Holtzman DM, Zlokovic BV: IgG-assisted age-dependent clearance of Alzheimer's amyloid beta peptide by the blood-brain barrier neonatal Fc receptor. J Neurosci 2005, 25:11495-503.

26. Solomon B, Koppel R, Hanan E, Katzav T: Monoclonal antibodies inhibit in vitro fibrillar aggregation of the Alzheimer beta-amyloid peptide. Proc Natl Acad Sci USA 1996, 93:452-5.

27. Nimmerjahn F, Ravetch JV: Anti-inflammatory actions of intravenous immunoglobulin. Annu Rev Immunol 2008, 26:513-33.

28. Fillit $H$, Hess $G$, Hill J, Bonnet $P$, Toso C: IV immunoglobulin is associated with a reduced risk of Alzheimer disease and related disorders. Neurology 2009, 73:180-5.

29. Relkin NR, Szabo P, Adamiak B, Burgut T, Monthe C, Lent RW, Younkin S, Younkin $L$, Schiff $R$, Weksler ME: 18-Month study of intravenous immunoglobulin for treatment of mild Alzheimer disease. Neurobiol Aging 2009, 30:1728-36.

30. Du Y, Dodel R, Hampel H, Buerger K, Lin S, Eastwood B, Bales K, Gao F, Moeller HJ, Oertel W, Farlow M, Paul S: Reduced levels of amyloid betapeptide antibody in Alzheimer disease. Neurology 2001, 57:801-5.

31. Weksler ME, Relkin N, Turkenich R, LaRusse S, Zhou L, Szabo P: Patients with Alzheimer disease have lower levels of serum anti-amyloid peptide antibodies than healthy elderly individuals. Exp Gerontol 2002, 37:943-8.

32. Moir RD, Tseitlin KA, Soscia S, Hyman BT, Irizarry MC, Tanzi RE: Autoantibodies to redox-modified oligomeric Abeta are attenuated in the plasma of Alzheimer's disease patients. J Biol Chem 2005, 280:17458-63.

33. Henkel AW, Dittrich PS, Groemer TW, Lemke EA, Klingauf J, Klafki HW, Lewczuk P, Esselmann H, Schwille P, Kornhuber J, Wiltfang J: Immune complexes of auto-antibodies against Abeta 1-42 peptides patrol cerebrospinal fluid of non-Alzheimer's patients. Mol Psychiatry 2007, 12:601-10.

34. Britschgi M, Olin CE, Johns HT, Takeda-Uchimura Y, LeMieux MC, Rufibach $\mathrm{K}$, Rajadas J, Zhang H, Tomooka B, Robinson WH, Clark CM, Fagan AM, Galasko DR, Holtzman DM, Jutel M, Kaye JA, Lemere CA, Leszek J, Li G, Peskind ER, Quinn JF, Yesavage JA, Ghiso JA, Wyss-Coray T: Neuroprotective natural antibodies to assemblies of amyloidogenic peptides decrease with normal aging and advancing Alzheimer's disease. Proc Natl Acad Sci USA 2009, 106:12145-50.

35. Kellner A, Matschke J, Bernreuther C, Moch H, Ferrer I, Glatzel M: Autoantibodies against beta-amyloid are common in Alzheimer's disease and help control plaque burden. Ann Neurol 2009, 65:24-31.
36. Arumugam TV, Tang SC, Lathia JD, Cheng A, Mughal MR, Chigurupati S, Magnus T, Chan SL, Jo DG, Ouyang X, Fairlie DP, Granger DN, Vortmeyer A, Basta M, Mattson MP: Intravenous immunoglobulin (IVIG) protects the brain against experimental stroke by preventing complement-mediated neuronal cell death. Proc Natl Acad Sci USA 2007, 104:14104-9.

37. Walberer M, Nedelmann M, Ritschel N, Mueller C, Tschernatsch M, Stolz E, Bachmann G, Blaes F, Gerriets T: Intravenous immunoglobulin reduces infarct volume but not edema formation in acute stroke. Neuroimmunomodulation 2010, 17:97-102.

38. Dodel R, Hampel H, Depboylu C, Lin S, Gao F, Schock S, Jackel S, Wei X, Buerger K, Hoft C, Hemmer B, Moller HJ, Farlow M, Oertel WH, Sommer N, Du Y: Human antibodies against amyloid beta peptide: a potential treatment for Alzheimer's disease. Ann Neurol 2002, 52:253-6.

39. Du Y, Wei X, Dodel R, Sommer N, Hampel H, Gao F, Ma Z, Zhao L, Oertel WH, Farlow M: Human anti-beta-amyloid antibodies block betaamyloid fibril formation and prevent beta-amyloid-induced neurotoxicity. Brain 2003, 126:1935-9.

40. Istrin G, Bosis E, Solomon B: Intravenous immunoglobulin enhances the clearance of fibrillar amyloid-beta peptide. J Neurosci Res 2006, 84:434-43.

41. Jankowsky JL, Fadale DJ, Anderson J, Xu GM, Gonzales V, Jenkins NA, Copeland NG, Lee MK, Younkin LH, Wagner SL, Younkin SG, Borchelt DR: Mutant presenilins specifically elevate the levels of the 42 residue betaamyloid peptide in vivo: evidence for augmentation of a 42-specific gamma secretase. Hum Mol Genet 2004, 13:159-70.

42. O'Nuallain B, Hrncic R, Wall JS, Weiss DT, Solomon A: Diagnostic and therapeutic potential of amyloid-reactive $\lg G$ antibodies contained in human sera. J Immunol 2006, 176:7071-8.

43. Brewer GJ, Torricelli JR, Evege EK, Price PJ: Optimized survival of hippocampal neurons in B27-supplemented Neurobasal, a new serumfree medium combination. J Neurosci Res 1993, 35:567-76.

44. Kanninen K, Malm TM, Jyrkkanen HK, Goldsteins G, Keksa-Goldsteine V Tanila H, Yamamoto M, Yla-Herttuala S, Levonen AL, Koistinaho J: Nuclear factor erythroid 2-related factor 2 protects against beta amyloid. Mol Cell Neurosci 2008, 39:302-13.

45. LeVine H III: Thioflavine T interaction with synthetic Alzheimer's disease beta-amyloid peptides: detection of amyloid aggregation in solution. Protein Sci 1993, 2:404-10

46. Hanisch UK, van Rossum D, Xie Y, Gast K, Misselwitz R, Auriola S, Koistinaho J, Kettenmann H, Moller T: The microglia-activating potential of thrombin: the protease is not involved in the induction of proinflammatory cytokines and chemokines. J Biol Chem 2004, 279:51880-7.

47. Malm TM, Magga J, Kuh GF, Vatanen T, Koistinaho M, Koistinaho J: Minocycline reduces engraftment and activation of bone marrowderived cells but sustains their phagocytic activity in a mouse model of Alzheimer's disease. Glia 2008, 56:1767-79.

48. Hartig W, Reichenbach A, Voigt C, Boltze J, Bulavina L, Schuhmann MU, Seeger J, Schusser GF, Freytag C, Grosche J: Triple fluorescence labelling of neuronal, glial and vascular markers revealing pathological alterations in various animal models. J Chem Neuroanat 2009, 37:128-38.

49. Yoshimori T, Yamamoto A, Moriyama Y, Futai M, Tashiro Y: Bafilomycin A1, a specific inhibitor of vacuolar-type $\mathrm{H}(+)$-ATPase, inhibits acidification and protein degradation in lysosomes of cultured cells. J Biol Chem 1991, 266:17707-12.

50. Dahlgren KN, Manelli AM, Stine WB, Baker LK Jr, Krafft GA, LaDu MJ: Oligomeric and fibrillar species of amyloid-beta peptides differentially affect neuronal viability. J Biol Chem 2002, 277:32046-53.

51. Szabo P, Relkin N, Weksler ME: Natural human antibodies to amyloid beta peptide. Autoimmun Rev 2008, 7:415-20

52. Bacskai BJ, Kajdasz ST, McLellan ME, Games D, Seubert P, Schenk $D$, Hyman BT: Non-Fc-mediated mechanisms are involved in clearance of amyloid-beta in vivo by immunotherapy. J Neurosci 2002, 22:7873-8.

53. Wilcock DM, Munireddy SK, Rosenthal A, Ugen KE, Gordon MN, Morgan D: Microglial activation facilitates Abeta plaque removal following intracranial anti-Abeta antibody administration. Neurobiol Dis 2004, 15:11-20.

54. Klaver AC, Finke JM, Digambaranath J, Balasubramaniam M, Loeffler DA: Antibody concentrations to Abeta1-42 monomer and soluble oligomers in untreated and antibody-antigen-dissociated intravenous immunoglobulin preparations. Int Immunopharmacol 2010, 10:115-9. 
55. Balakrishnan K, Andrei-Selmer LC, Selmer T, Bacher M, Dodel R: Comparison of intravenous immunoglobulins for naturally occurring autoantibodies against amyloid-beta. J Alzheimers Dis 2010, 20:135-43.

56. Malm TM, livonen H, Goldsteins $G$, Keksa-Goldsteine V, Ahtoniemi T, Kanninen K, Salminen A, Auriola S, Van Groen T, Tanila H, Koistinaho J: Pyrrolidine dithiocarbamate activates Akt and improves spatial learning in APP/PS1 mice without affecting beta-amyloid burden. J Neurosci 2007, 27:3712-21.

57. Malm T, Ort M, Tahtivaara L, Jukarainen N, Goldsteins G, Puoliväli J, Nurmi A, Pussinen R, Ahtoniemi T, Miettinen TK, Kanninen K, Leskinen S, Vartiainen N, Yrjänheikki J, Laatikainen R, Harris-White ME, Koistinaho M, Frautschy SA, Bures J, Koistinaho J: beta-Amyloid infusion results in delayed and age-dependent learning deficits without role of inflammation or beta-amyloid deposits. Proc Natl Acad Sci USA 2006, 103:8852-7.

58. Nicoll JA, Barton E, Boche D, Neal JW, Ferrer I, Thompson P, Vlachouli C, Wilkinson D, Bayer A, Games D, Seubert P, Schenk D, Holmes C: Abeta species removal after abeta42 immunization. J Neuropathol Exp Neurol 2006, 65:1040-8.

59. Mentlein R, Ludwig R, Martensen I: Proteolytic degradation of Alzheimer's disease amyloid beta-peptide by a metalloproteinase from microglia cells. J Neurochem 1998, 70:721-6.

60. Qiu WQ, Ye Z, Kholodenko D, Seubert P, Selkoe DJ: Degradation of amyloid beta-protein by a metalloprotease secreted by microglia and other neural and non-neural cells. J Biol Chem 1997, 272:6641-6.

61. Ito S, Kimura K, Haneda M, Ishida Y, Sawada M, Isobe K: Induction of matrix metalloproteinases (MMP3, MMP12 and MMP13) expression in the microglia by amyloid-beta stimulation via the PI3K/Akt pathway. Exp Gerontol 2007, 42:532-7.

62. Pul R, Kopadze T, Skripuletz T, Voss EV, Kieseier BC, Stangel M: Polyclonal immunoglobulins (IVIg) induce expression of MMP-9 in microglia. J Neuroimmunol 2009, 217:46-50.

63. Majumdar A, Chung H, Dolios G, Wang R, Asamoah N, Lobel P, Maxfield FR: Degradation of fibrillar forms of Alzheimer's amyloid beta-peptide by macrophages. Neurobiol Aging 2008, 29:707-15.

64. Majumdar A, Cruz D, Asamoah N, Buxbaum A, Sohar I, Lobel P, Maxfield FR: Activation of microglia acidifies lysosomes and leads to degradation of Alzheimer amyloid fibrils. Mol Biol Cell 2007, 18:1490-6.

65. Anthony RM, Wermeling F, Karlsson MC, Ravetch JV: Identification of a receptor required for the anti-inflammatory activity of IVIG. Proc Natl Acad Sci USA 2008, 105:19571-8.

66. Wilcock DM, DiCarlo G, Henderson D, Jackson J, Clarke K, Ugen KE, Gordon MN, Morgan D: Intracranially administered anti-Abeta antibodies reduce beta-amyloid deposition by mechanisms both independent of and associated with microglial activation. I Neurosci 2003, 23:3745-51.

67. Poduslo JF, Ramakrishnan M, Holasek SS, Ramirez-Alvarado M, Kandimalla KK, Gilles EJ, Curran GL, Wengenack TM: In vivo targeting of antibody fragments to the nervous system for Alzheimer's disease immunotherapy and molecular imaging of amyloid plaques. J Neurochem 2007, 102:420-33.

68. Banks WA, Terrell B, Farr SA, Robinson SM, Nonaka N, Morley JE: Passage of amyloid beta protein antibody across the blood-brain barrier in a mouse model of Alzheimer's disease. Peptides 2002, 23:2223-6.

doi:10.1186/1742-2094-7-90

Cite this article as: Magga et al: Human intravenous immunoglobulin provides protection against $A \beta$ toxicity by multiple mechanisms in a mouse model of Alzheimer's disease. Journal of Neuroinflammation 2010 7:90.

\section{Submit your next manuscript to BioMed Central and take full advantage of:}

- Convenient online submission

- Thorough peer review

- No space constraints or color figure charges

- Immediate publication on acceptance

- Inclusion in PubMed, CAS, Scopus and Google Scholar

- Research which is freely available for redistribution

Submit your manuscript at www.biomedcentral.com/submit
Biomed Central 